\title{
Cotton development and yield according to nitrogen application and cover crops
}

\section{Desenvolvimento e produtividade do algodoeiro submetido a doses de nitrogênio e plantas de cobertura}

\author{
Samuel Ferrari ${ }^{1}$; Enes Furlani Junior ${ }^{2 *}$; João Vitor Ferrari³; \\ Gustavo Alves Pereira ${ }^{3}$
}

\begin{abstract}
Nitrogen application on the cover and the maintenance of straw, conducted by direct seeding, should meet the needs of agriculture and promote soil conservation. This study evaluates the effect of presowing nitrogen application in cotton crops and cover crops by direct seeding, on the development and yield of cotton. It was conducted in the municipality of Selvíria-MS during the agricultural years $2005 / 06,2006 / 07$ and 2007/08. The experimental design used was a randomized block design consisting of three cover crops (forage turnip, black oat and white oat) and four nitrogen doses $(0,30,60$ and 90 $\mathrm{kg}$ of $\mathrm{N} \mathrm{ha}^{-1}$ ) in pre-sowing of cotton. In April 2006, April 2007 and April 2008, the assessments of plant development and also harvesting of the experimental plots of cotton cultivars were conducted. The results showed that after planting the cover crops, the yield and development and the heights of cotton plants increased with the use of pre-sowing $\mathrm{N}$ of $90 \mathrm{~kg} \mathrm{ha}^{-1}$, also showing that the forage turnip is a coverage plant that provides increased cotton.
\end{abstract}

Key words: Gossypium hirsutum, ammonium sulfate, cover crops and yield

\section{Resumo}

A aplicação de nitrogênio em cobertura e a manutenção da palhada, realizadas na semeadura direta, devem respectivamente, atender as necessidades da cultura e promover a conservação do solo. O presente trabalho teve por objetivo avaliar o efeito da aplicação de nitrogênio em pré-semeadura do algodoeiro e das plantas de cobertura, implantadas em semeadura direta, sobre o desenvolvimento e produtividade do algodoeiro. O estudo foi realizado no município de Selvíria-MS durante os anos agrícolas de 2005/06, 2006/07 and 2007/08. O delineamento experimental empregado foi o de blocos ao acaso composto por três plantas de cobertura (nabo forrageiro, aveia preta e aveia branca) e quatro doses de nitrogênio $(0,30$, 60 , e $90 \mathrm{~kg}$ de $\mathrm{N} \mathrm{ha}^{-1}$ ) aplicadas sobre a palhada do milheto e em pré-semeadura do algodoeiro. No mês de abril de 2006, abril de 2007 e abril de 2008 foram realizadas as avaliações de desenvolvimento de plantas e também realizada as colheitas das parcelas experimentais da cultura do algodoeiro. De acordo com os resultados obtidos verifica-se que após a instalação das plantas de cobertura, a produtividade e o desenvolvimento em alturas, das plantas do algodoeiro aumentaram em função da utilização de doses de $\mathrm{N}$ até $90 \mathrm{~kg} \mathrm{ha}^{-1} \mathrm{em}$ pré-semeadura e que o nabo forrageiro é uma planta de cobertura que proporciona aumento da produtividade do algodoeiro.

Palavras-chave: Gossypium hirsutum, sulfato de amônio, culturas de cobertura e produtividade

${ }^{1}$ Prof. Dr. da Universidade Estadual Paulista “Júlio de Mesquita Filho", UNESP.Campus Experimental de Registro, R. Nelson Brihi Badur, 430, 11900-000. Registro, SP. E-mail: ferrari@registro.unesp.br

2 Prof. Titular do Departamento de Fitotecnia da UNESP/Campus de Ilha Solteira, Av. Brasil, 56, Ilha Solteira, SP. E-mail: enes@ agr.feis.unesp.br

3 Doutorandos em Agronomia, UNESP/Campus de Ilha Solteira, SP. E-mail: gustavo_apereira@yahoo.com.br; ferrari_agro@, hotmail.com

* Autor para correspondência 


\section{Introduction}

Brazil is currently the fourth largest exporter and fifth largest cotton producer worldwide, with the highest production led by the State of Mato Grosso. The initial chemical analysis in most of the soils of the Brazilian savannahs, especially regarding the states of MT, BA and MS, indicated a high nutrient deficiency, which in principle could justify the intensive use of fertilizers. However, some experimental results indicate the possibility of obtaining high $\mathrm{s}$ in fertilizer levels below those prevailing in large crops that are typical of the cerrado regions. According to Silva (1999), soil analysis is an essential tool to assess the needs of plants. However, in the case of nitrogen, especially under cerrado conditions, there is still no referential index that enables trustworthy information.

Among the effects of nitrogen fertilization on the characteristics of cotton, the influence on the development, precocity and stand out. In addition, it can also improve the fiber's quality aspects (SILVA; KONDO; SABINO, 1994).

In the search for a system that reduces soil loss and promotes the use of water, no-tillage has been characterized for having, especially on the surface layer, greater structural stability, which combined with the maintenance of crop residues on the soil surface, have provided greater protection against the direct impact of raindrops, promoting infiltration and reducing water loss by surface runoff $(\mathrm{ROTH}$; VIEIRA, 1983).

The importance of cover crops has long been acknowledged in agriculture. The use of this cultivation practice can maintain or increase crop performance, reducing soil erosion, increasing organic matter content, improving the physical qualities of soil and decreasing the use of inputs (nitrogen fertilizer and pesticides) (HOLDERBAUM et al., 1990, MEINSINGER et al., 1991).

Another important factor is the cultivation of species with vigorous root systems, which enables creating channels in the soil and promotes the right conditions for the subsequent crops' development of roots. In addition, species that have a deep root and ramified system can remove nutrients from the subsurface layers, and release them gradually onto the surface layers during the decomposition process, helping to maintain the balance of nutrients in the soil and increase its fertility, as well as enabling a better use of the agricultural inputs, (WANG; HESKETH, WOOLLEY, 1986).

Thus, this study evaluates the effect of presowing nitrogen application in cotton crops and cover crops by direct seeding, on the development and yield of cotton.

\section{Material and Methods}

The study was carried out at the municipality of Selvíria-MS. The geographical coordinates of the study area are $20^{\circ} 20^{\prime}$ South Latitude and $51^{\circ} 24$ West Longitude, and an average altitude of $344 \mathrm{~m}$. The climate of the region classified by Köppen as Aw, is defined as tropical humid with a rainy summer season and dry winter. It has an annual average temperature of $24.5^{\circ} \mathrm{C}$, average annual rainfall of $1.232 \mathrm{~mm}$.

The soil was classified as very clayey typical dystrophic RED LATOSOL, in agreement with the Brazilian soil classification (EMBRAPA, 2006). In June 2005, soil sampling was performed to characterize the chemical analysis following the methodology described by Raij and Quaggio, (1983). The experimental design used randomized blocks laid out in zones (GOMES, 2000), consisting of four nitrogen doses $\left(0,30,60\right.$ and $\left.90 \mathrm{~kg} \mathrm{~N} \mathrm{ha}^{-1}\right)$ applied to cotton pre-seeding and millet straw. The millet was sown in August and submitted to glifosate application prior to implantation of cotton crop. bthree cover crops (forage turnip, black oat and white oat) planted in zones after the winter cotton harvest.

In 2004, the area used had the cotton crop under conventional tillage. In July 2005, the soil was prepared to a depth of $30 \mathrm{~cm}$, using a mould-board 
plow. Along with the harrow operation, and to raise the base saturation to $70 \%$ (SILVA; RAIJ, 1997), the application of $1 \mathrm{t} \mathrm{ha} \mathrm{a}^{-1}$ of limestone was performed according to the previous soil analysis (Table 1).

Table 1. Results of the chemical analysis of the soil at a depth of 0 to $20 \mathrm{~cm}$. Selvíria-MS, 2005.

\begin{tabular}{|c|c|c|c|c|c|c|c|c|c|}
\hline $\mathbf{P}_{\text {resina }}$ & M.O. & pH & $\mathbf{K}$ & Ca & Mg & $\mathbf{H}+\mathbf{A l}$ & Al & СТC & $\mathbf{V}$ \\
\hline $\mathrm{mg} / \mathrm{dm}^{3}$ & $\mathrm{~g} / \mathrm{dm}^{3}$ & $\left(\mathrm{CaCl}_{2}\right)$ & & \multicolumn{5}{|c|}{$\mathrm{mmol}_{\mathrm{c}} / \mathrm{dm}^{3}$} & $(\%)$ \\
\hline 10 & 24 & 4.9 & 4.6 & 18 & 10 & 24 & 0 & 57 & 57 \\
\hline
\end{tabular}

For the 3 years of the agricultural work carried out, the activities took place at similar dates, with the sowing of millet performed on September 9, 2005, August 24, 2006 and August 28, 2007, all in the same way, with spacing of $0.45 \mathrm{~m}$ and $10 \mathrm{~kg}$ $\mathrm{ha}^{-1}$ of seeds, using straw in the area (GUIDELI; FAVORETO; MALHEIRIOS, 2000), which provided mulch of 7, 6 and $6 \mathrm{tha}^{-1}$ respectively, for the crop years 2005/06, 2006/07 and 2007/08. After developing this culture, desiccation was carried out by applying the herbicide glyphosate at a dose of $4 \mathrm{~L} \mathrm{ha}^{-1}$, then crushed using a Triton accessory coupled to a tractor.

After grinding the millet, as part of the treatments under study, the nitrogen doses were applied manually (cotton pre-sowing fertilization) with the ammonium sulfate fertilizer $(20 \% \mathrm{~N}$ and $24 \% \mathrm{~S}$ ) onto the surface of the millet straw, following the initial test design and the same layouts of the plots. The dates were November 16, 2005, November 17, 2006 and November 20, 2007.

The no-till cotton on the millet straw was performed in the same manner for the three study years, with a density of 11 seeds per meter and using the cotton cultivar Deltaopal. The seedlings emerged 5 days after sowing.

The fertilization of cotton sowing was performed without nitrogen application, but followed the recommendations of Silva and Raij (1997) for P and K that, based on soil analysis (Table 1), used $100 \mathrm{~kg} \mathrm{ha}^{-1}$ of $\mathrm{P}_{2} \mathrm{O}_{5}$ (simple superphosphate) and $60 \mathrm{~kg}$ ha- 1 of $\mathrm{K}_{2} \mathrm{O}$ (potassium chloride) for the three years of study.

The growth regulator mepiquat chloride (PIX) was applied only once, always at 70 d.a.e. for the three cotton cultivation years, using a sprayer with a dose of $1.0 \mathrm{~L} \mathrm{ha}^{-1}$ of the commercial product, The spraying was carried out in the morning in order to avoid the high temperatures throughout the day.

The control of pests and diseases was conducted for the efficient development of the cotton plants in such a manner as to not interfere with the treatments under study.

Each experimental parcel consisted of four rows with five meters in length and spacing of $0.9 \mathrm{~m}$, with the useful area consisting of the two central lines of the parcel. After these seedlings emerged, they were thinned, leaving 8 plants per meter.

All of the collection procedures in the experimental plots were conducted by manually removing all the cotton bolls from the two central rows for subsequent weighing. The harvest activities took place on April 21, 2006, April 25, 2007 and April 24, 2008. After the cotton harvest, the cotton rootstocks were cleared using a brush cutter coupled to a tractor.

On $06 / 05 / 06$ and 11/05/07 the cover crops were sowed (black oat, white oat and forage turnip) as part of the treatments under study, 
always in the same layouts of the parcels, which before had the cotton crops. This seeding was performed in zones, with a spacing of $17 \mathrm{~cm}$. The sowing densities were $30 \mathrm{~kg} \mathrm{ha}^{-1}$ for turnip straw and $50 \mathrm{~kg} \mathrm{ha}^{-1}$ for white and black oats for both sowings.

The seeding of the cover crops did not have the addition of fertilizer. For the emergence and establishment of the cultures, the irrigation was carried out using a self-propelled reel winder equipped with an adjustable sprinkler/cannon flow belonging to the farm where the work was performed.

The collection of the aerial cover crops was conducted on August 10, 2006 and August 14, 2007 using a machete to cut at all the crops at $2 \mathrm{~cm}$ from the soil. This vegetal material was transferred to a forced-air greenhouse heater (Phytotechny Department FE/UNESP / Ilha Solteira) at a temperature of $60^{\circ} \mathrm{C}$ for 72 hours. Next, the dry matter was weighed and the constant weight was checked. The dry weight of the forage turnip was of $2105 \mathrm{~kg}$ dry matter (DM) ha-1, for the black oat the weight was of $1950 \mathrm{~kg} \mathrm{DM} \mathrm{ha}{ }^{-1}$, and for the white oat it was of $1720 \mathrm{~kg} \mathrm{DM} \mathrm{ha}^{-1}$ in the crop year 2006/07 and for the crop year 2007/08 the dry weight of forage turnip was of $2238 \mathrm{~kg} \mathrm{DM} \mathrm{ha}^{-1}$, for the black oat was the weight was of $2145 \mathrm{~kg} \mathrm{DM} \mathrm{ha}^{-1}$, and for the white oat it was of $2104 \mathrm{~kg} \mathrm{DM} \mathrm{ha}^{-1}$.

On the day after the aerial harvesting, the desiccation of the winter crops was performed by applying glyphosate at a dose of $3 \mathrm{~L} \mathrm{ha}^{-1}$. After the herbicide was applied, no mulch destruction activity was carried out.

The agronomic characteristics were assessed in ten plants in the sequence of a single line in each plot, for the three years of assessments. The characteristics of the average number of reproductive and vegetative stems performed were assessed by counting during the collection; plant height from soil to the apex, using a tape measure; stem diameter using calipers, $2 \mathrm{~cm}$ in height from the soil; mass of 1 capsule performed by random sampling of 20 capsules in both central lines of the parcels in the middle third of the plants, during harvest. After weighing on a digital scale, the mass of 1 capsule was obtained by dividing the value found; the cotton seed production obtained by manual harvesting of both central rows in each plot, followed by weighing in a digital scale.

The data obtained in this study underwent analysis of variance by $\mathrm{F}$ test and comparison tests of the averages (Tukey) and polynomial regression at a significance level of $\mathrm{p}>0,05$ using the methodology described by Gomes (2000).

\section{Results and Discussion}

Table 2 shows the assessments values of growth characteristics for the cv. Deltaopal cotton plants conducted at harvest time, as a function of the use of $\mathrm{N}$ for the crop year 2005/06.

By comparing the averages, it was found that by counting the number of vegetative and reproductive stems (Table 2) found in the plants, there was no significant difference for the use of increasing nitrogen doses.

Similar to the height and diameter assessment, measured during the cotton harvest, no significant difference was verified when using the fertilizer doses in the study. These results are consistent with those found by Teixeira; Kikuti and Borém (2008), that using different nitrogen doses combined with the use of growth regulators, did not find differences in plant height at 90 d.a.e., for the doses studied. 
Table 2. $\mathrm{p}>\mathrm{F}$ values and mean comparison test to analyze agronomic traits of cotton as a function of presowing fertilization. Selvíria-MS, crop year 2005/06.

\begin{tabular}{|c|c|c|c|c|}
\hline$\overline{\text { F Test }}$ & Reproductive Stems & $\begin{array}{c}\text { Vegetal Stems } \\
\mathbf{p}>\mathbf{F}\end{array}$ & Height & Diameter \\
\hline$\overline{\operatorname{Doses}(\mathrm{d})}$ & 0,233 & 0,753 & 0,579 & 0,065 \\
\hline \multirow[t]{3}{*}{ C.V.\% } & 9,000 & 16,210 & 4,420 & 7,310 \\
\hline & \multicolumn{4}{|c|}{ Polinomial Regression } \\
\hline & $\left(n^{0}\right)$ & $\left(n^{0}\right)$ & (m) & (cm) \\
\hline 0 & 14,300 & 2,160 & 1,170 & 1,330 \\
\hline 30 & 13,610 & 2,110 & 1,180 & 1,280 \\
\hline 60 & 14,160 & 2,020 & 1,190 & 1,380 \\
\hline 90 & 14,690 & 1,880 & 1,190 & 1,370 \\
\hline $\mathrm{p}>\mathrm{F}$ (linear) & 0,302 & 0,287 & 0,149 & 0,115 \\
\hline $\mathrm{p}>\mathrm{F}$ (quadratic) & 0,101 & 0,819 & 0,5820 & 0,562 \\
\hline $\mathrm{r}^{2}($ linear $\%)$ & 24,700 & 95,800 & 73,250 & 32,620 \\
\hline $\mathrm{r}^{2}$ (quadrática \%) & 86,500 & 99,800 & 96,900 & 40,720 \\
\hline
\end{tabular}

$* *$, Significant at $1 \%$ and $5 \%$ levels, respectively, by the $\mathrm{F}$ Test of analysis of variance.

Table 3 shows the assessment results for growth characteristics of cotton plants conducted in $2006 / 07$ according to different treatments.

The results show that as the $\mathrm{N}$ doses applied were increased, the cotton plant heights increased, with $1.24 \mathrm{~m}$ representing the highest measure found for the highest dose applied $\left(90 \mathrm{~kg} \mathrm{~N} \mathrm{ha}^{-1}\right)$. These results corroborate those found by Furlani Júnior et al. (2003); which reported that with the nitrogen application up to $70 \mathrm{~kg} \mathrm{ha}^{-1}$, the highest plant heights were found, when compared with the dose of $30 \mathrm{~kg} \mathrm{~N} \mathrm{ha}^{-1}$.

On the other hand, no significant difference could be verified for plant heights (Table 3 ) when using different cover crops in winter.

For the assessments of the main plant stems' basal diameter and the number of reproductive and vegetal stems, no significant differences were found among the treatment averages when the pre-sowing $\mathrm{N}$ doses were increased. Similarly, there were no significant differences in the averages for the use of cover crops (Table $3)$.

Evaluating plant height based on the preseeding nitrogen doses, it was noted that cotton responded linearly to the increasing doses, showing greater heights $(1.49 \mathrm{~m})$ at a dose of 90 $\mathrm{kg} \mathrm{N} \mathrm{ha}^{-1}$. These results disagree with those found by Lima et al. (2006), that when using increasing doses of nitrogen (up to $240 \mathrm{~kg} \mathrm{~N} \mathrm{ha}^{-1}$ ), divided into two periods (34 and 51 d.a.e.) for the BRS Verde cultivar, under greenhouse conditions, there were no significant responses for plant height, assessed at 120 d.a.e. as a function of the doses applied. Similarly, these results are different from those found by Lamas and Staut (2005) that assessed cotton plant heights in response to nitrogen fertilization associated with the application of mepiquat chloride, and found no significant differences in the averages presented. 
Table 3. $\mathrm{p}>\mathrm{F}$ comparison and test values of averages for analysis of agronomic cotton characteristics as a function of fertilization in pre-sowing and cover crops Selvíria-MS, crop year 2006/07.

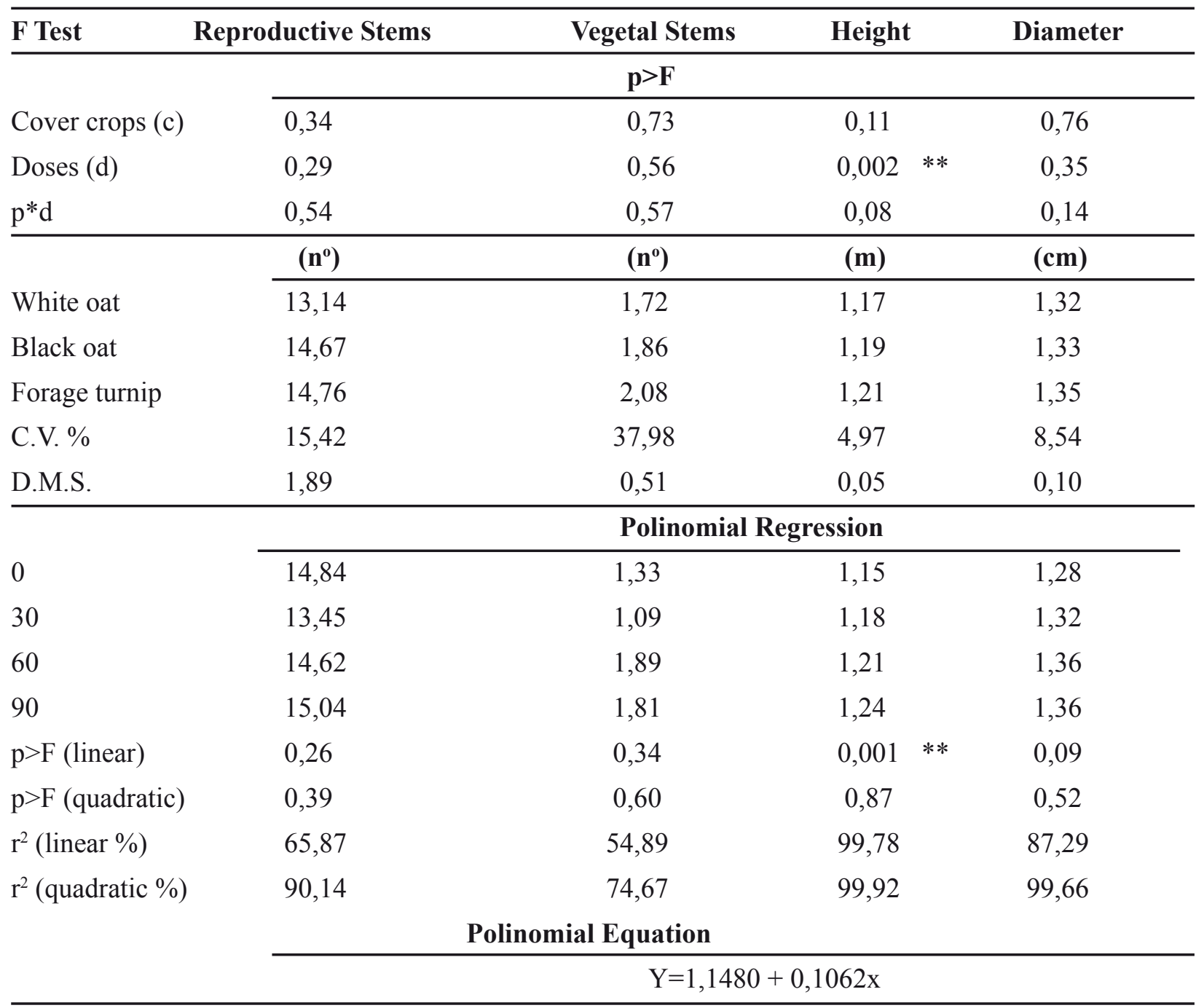

**, * Significant at levels of $1 \%$ and $5 \%$, respectively, by the $\mathrm{F}$ Test of the analysis of variance.

With respect to the basal diameter of the main plant stems at harvest time (Table 4), it was observed that the nitrogen doses under study did not significantly influence the averages presented. These results disagree with those found by Lima et al. (2006), that when using increasing doses of $\mathrm{N}$ applied to the cover, found higher stem diameter values $(1.05 \mathrm{~cm})$ for the dose of $160 \mathrm{~kg} \mathrm{~N} \mathrm{ha}^{-1}$.

However plant diameters were greater when using black oat as cover crop in winter, differing from white oat by $0.59 \mathrm{~cm}$ (Table 4).

When the number of reproductive stems in the plant were assessed (Table 4), a significant difference was observed for the averages as a function of the $\mathrm{N}$ doses used. It was seen that there was an increase of 1 reproductive stem per plant, when using the maximum dose of $\mathrm{N}$, when compared to the nonuse of fertilizer. However, when assessing the effect of cover crops on this characteristic, no significant changes were observed in the averages. 
Table 4. $p>F$ test and mean comparison values for analysis of agronomic cotton characteristics as a function of pre-sowing fertilization and cover crops. Selvíria-MS, crop year 2007/08.

\begin{tabular}{|c|c|c|c|c|c|c|}
\hline \multirow{3}{*}{$\begin{array}{l}\text { F Test } \\
\text { Cover crops (c) }\end{array}$} & \multicolumn{2}{|c|}{ Reproductive Stems } & \multirow{2}{*}{$\begin{array}{r}\text { Vegetal Stems } \\
\mathbf{p}>\mathbf{F}\end{array}$} & \multicolumn{2}{|c|}{ Height } & Diameter \\
\hline & & & & & & \\
\hline & 0,41 & & 0,67 & 0,04 & $*$ & $0,008 * *$ \\
\hline Doses $(d)$ & 0,05 & $*$ & 0,22 & 0,01 & $*$ & 0,92 \\
\hline \multirow[t]{2}{*}{$\mathrm{p}^{*} \mathrm{~d}$} & 0,11 & & 0,60 & 0,71 & & 0,98 \\
\hline & $\left(n^{0}\right)$ & & $\left(n^{0}\right)$ & (m) & & $(\mathrm{cm})$ \\
\hline White Oat & 15,75 & & 0,83 & 1,42 & $\mathrm{~b}$ & $1,41 \quad b$ \\
\hline Black Oat & 16,00 & & 0,91 & 1,49 & $\mathrm{a}$ & $2,00 \quad a$ \\
\hline Forage turnip & 16,16 & & 1,00 & 1,45 & $a b$ & $1,66 \mathrm{ab}$ \\
\hline C.V. $\%$ & 4,74 & & 4,93 & 4,51 & & 24,46 \\
\hline \multirow[t]{2}{*}{ D.M.S. } & 0,77 & & 0,46 & 0,06 & & 0,42 \\
\hline & \multicolumn{6}{|c|}{ Polinomial Regression } \\
\hline 0 & 15,33 & & 0,88 & 1,39 & & 1,65 \\
\hline 30 & 16,11 & & 0,66 & 1,48 & & 1,77 \\
\hline 60 & 16,20 & & 1,00 & 1,47 & & 1,66 \\
\hline 90 & 16,33 & & 1,11 & 1,49 & & 1,66 \\
\hline $\mathrm{p}>\mathrm{F}$ (linear) & 0,014 & $*$ & 0,15 & 0,005 & $* *$ & 0,85 \\
\hline $\mathrm{p}>\mathrm{F}$ (quadratic) & 0,28 & & 0,28 & 0,09 & & 0,69 \\
\hline $\mathrm{r}^{2}($ linear \%) & 77,97 & & 46,29 & 67,69 & & 6,67 \\
\hline \multirow[t]{3}{*}{$\mathrm{r}^{2}$ (quadratic \%) } & 91,34 & & 72,00 & 90,10 & & 40,00 \\
\hline & \multicolumn{6}{|c|}{ Polinomial Equation } \\
\hline & \multicolumn{2}{|c|}{$Y=15,52+0,010 x$} & \multicolumn{3}{|c|}{$Y=141,522+0,1007 x$} & \\
\hline
\end{tabular}

**, * Significant at levels of $1 \%$ and $5 \%$, respectively, by the $\mathrm{F}$ Test of the analysis of variance.

Averages followed by the same letter in the vertical do not differ among themselves by the Tukey test at $5 \%$ probability.

For the number of vegetative stems per plant, there was no significant change in the values for different treatments (Table 4).

Table 5 shows the mean mass of 1 cotton boll and cotton seed due to the application of different doses of $\mathrm{N}$, for the 2005/06 crop. For the result analysis, it appears that the $\mathrm{cv}$. Deltaopal increased the boll mass when $\mathrm{N}$ doses were increased, with a maximum value (4.72 $\mathrm{g}$ ) at a dose of $60 \mathrm{~kg} \mathrm{~N} \mathrm{ha}{ }^{-1}$. These results agree with those found by Teixeira, Kikuti and Borém 2008 that assessing the response of cv. FMX 986, due to using increasing doses of $\mathrm{N}$, also found significant mass differences for 1 boll, with the highest value $(6.7 \mathrm{~g})$ found for the application of $120 \mathrm{~kg} \mathrm{~N} \mathrm{ha}^{-1}$.

Silva et al. (2001) studied different nitrogen application doses having found that for the cotton seed yield, the averages increased up to a dose of $60 \mathrm{~kg} \mathrm{~N} \mathrm{ha} \mathrm{N}^{-1}$. 
Table 5. $\mathrm{p}>\mathrm{F}$ and test comparison values of averages for the weight 1 boll and cotton seed, cv. Deltaopal as a function of the treatments. Selvíria-MS, crop year 2005/06.

\begin{tabular}{|c|c|c|}
\hline$\overline{\text { F Test }}$ & Weight of 1 Boll & Yield \\
\hline \multirow[b]{2}{*}{ Doses $(d)$} & \multicolumn{2}{|l|}{$\mathbf{p}>\mathbf{F}$} \\
\hline & 0,04 & 0,33 \\
\hline \multirow[t]{3}{*}{ C.V. \% } & 6,34 & 13,12 \\
\hline & \multicolumn{2}{|c|}{ Polinomial Regression } \\
\hline & (g) & $\left(\mathrm{kg} \mathrm{ha}^{-1}\right)$ \\
\hline 0 & 4,45 & 1993,00 \\
\hline 30 & 4,47 & 2125,00 \\
\hline 60 & 4,72 & 2076,00 \\
\hline 90 & 4,69 & 2196,00 \\
\hline $\mathrm{p}>\mathrm{F}$ (linear) & 0,01 & 0,12 \\
\hline $\mathrm{p}>\mathrm{F}$ (quadratic) & 0,75 & 0,93 \\
\hline $\mathrm{r}^{2}($ linear \%) & 0,77 & 0,71 \\
\hline $\mathrm{r}^{2}$ (quadratic \%) & 0,75 & 0,71 \\
\hline
\end{tabular}

Polinomial Equation

$\mathrm{Y}=88,75+0,0656 \mathrm{x}$

**, * Significant at levels of $1 \%$ and $5 \%$, respectively, by the $\mathrm{F}$ Test of the analysis of variance.

Table 6 shows the cotton seed and the boll weight obtained by the study of applying increased levels of nitrogen combined with cover crops in the winter season. With the results observed, it can be stated that under the conditions of this study, the different winter cultures did not alter the mass of 1 boll. Similarly, no significant difference was found when applying increased doses of nitrogen fertilizer.

The use of $\mathrm{N}$ in pre-sowing also significantly influenced the yield of cv. Deltaopal, resulting in an increase up to the maximum dose applied (Table 6). The control group showed yield of $2231.54 \mathrm{~kg}$, while the dose of $90 \mathrm{~kg} \mathrm{~N}$ ha $^{-1}$ resulted in a yield of $2945.27 \mathrm{~kg}$, representing a rise of $713.73 \mathrm{~kg} \mathrm{ha}^{-1}$. These values were similar to those found by Silva et al. (1993) that reported the application of increased doses of nitrogen in the cotton cultivar, hence increasing the yield. Wiatrak et al. (2005) also found a yield increase, for cotton grown in North Florida - USA, up to doses of 134 and $202 \mathrm{~kg} \mathrm{~N} \mathrm{ha}^{-1}$ when compared to the control group.

Table 7 shows the averages of the weight of 1 boll and cotton seed for cv. Deltaopal for the treatments under study for the crop year 2007/08. With the results it was observed that for the mass of 1 boll, the different cover crops did not provide significant effect on the averages presented. Similarly, no significant differences were found with the use of increased doses of $\mathrm{N}$ applied to pre-sowing. 
Table 6. $\mathrm{p}>\mathrm{F}$ and test comparison values of averages for the weight of 1 boll and cotton seed, cv. Deltaopal as a function of the treatments. Selvíria-MS, crop year 2006/07.

\begin{tabular}{|c|c|c|}
\hline F Test & Weight of 1 Boll & Yield \\
\hline & \multicolumn{2}{|c|}{$\mathbf{p}>\mathbf{F}$} \\
\hline Cover crops (c) & 0,24 & $0,001 \quad * *$ \\
\hline Doses $(d)$ & 0,46 & $0,004 * *$ \\
\hline \multirow[t]{2}{*}{$\mathrm{p}^{*} \mathrm{~d}$} & 0,96 & 0,74 \\
\hline & (g) & $\left(\mathrm{kg} \mathrm{ha}^{-1}\right)$ \\
\hline White Oat & 4,86 & $2412,00 \mathrm{~b}$ \\
\hline Black Oat & 4,71 & $2363,00 \mathrm{~b}$ \\
\hline Forage turnip & 4,79 & $2988,00 \mathrm{a}$ \\
\hline C.V. $\%$ & 5,35 & 14,62 \\
\hline \multirow[t]{2}{*}{ D.M.S. } & 0,32 & 525,00 \\
\hline & \multicolumn{2}{|c|}{ Polinomial Regression } \\
\hline 0 & 4,71 & 2231,00 \\
\hline 30 & 4,74 & 2230,00 \\
\hline 60 & 4,86 & 2707,00 \\
\hline 90 & 4,84 & 2945,00 \\
\hline $\mathrm{p}>\mathrm{F}$ (linear) & 0,15 & $0,001 \quad * *$ \\
\hline $\mathrm{p}>\mathrm{F}$ (quadratic) & 0,76 & 0,82 \\
\hline$r^{2}($ linear \%) & 79,69 & 99,19 \\
\hline $\mathrm{r}^{2}$ (quadratic $\%$ ) & 84,01 & 98,40 \\
\hline
\end{tabular}

$\mathrm{Y}=2231,04+7,935917 \mathrm{x}$

**, * Significant at levels of $1 \%$ and $5 \%$, respectively, by the $\mathrm{F}$ Test of the analysis of variance.

Averages followed by the same letter in the vertical do not differ among themselves by the Tukey test at $5 \%$ probability.

In the yield assessment conducted in 2007/08 (Table 7), the different winter crops did not promote significant difference under the planting conditions of this study. However, when analyzing the use of $\mathrm{N}$ in pre-sowing, it was found that the averages show a significant positive linear response to the increased yield by using the doses. The variation between the maximum dose applied, and the absence of fertilization reached $678.52 \mathrm{~kg} \mathrm{ha}^{-1}$. These results agree with those found by Teixeira, Kikuti and Borém (2008) that when using increased doses of $\mathrm{N}$ applied in equal doses to the sowing and to the covers, found maximum s (3633 $\left.\mathrm{kg} \mathrm{ha}^{-1}\right)$ when using $131 \mathrm{~kg} \mathrm{~N}$ $\mathrm{ha}^{-1}$, when compared to the control group (3362 $\left.\mathrm{kg} \mathrm{ha}^{-1}\right)$. The results found by Lamas and Staut (2005), corroborate this report, when they had a significant effect on the cotton by the addition of up to $150 \mathrm{~kg} \mathrm{~N} \mathrm{ha}^{-1}$. 
Table 7. $\mathrm{p}>\mathrm{F}$ and test comparison values of averages for the weight of 1 boll and cotton seed, cv. Deltaopal as a function of the treatments. Selvíria-MS, crop year 2007/08.

\begin{tabular}{|c|c|c|c|}
\hline \multirow[t]{2}{*}{ F Test } & Weight of 1 Boll & Yield & \\
\hline & \multicolumn{3}{|c|}{$\mathbf{p}>\mathbf{F}$} \\
\hline Cover crops (c) & 0,14 & 0,76 & \\
\hline Doses (d) & 0,59 & 0,02 & $*$ \\
\hline \multirow[t]{2}{*}{$\mathrm{p}^{* \mathrm{~d}}$} & 0,59 & 0,52 & \\
\hline & (g) & $\left(\mathrm{kg} \mathrm{ha}^{-1}\right.$ & \\
\hline White Oat & 4,82 & 2762,00 & \\
\hline Black Oat & 4,58 & 2898,00 & \\
\hline Forage turnip & 4,89 & 2868,00 & \\
\hline C.V. $\%$ & 8,27 & 16,60 & \\
\hline \multirow[t]{2}{*}{ D.M.S. } & 0,40 & 484,29 & \\
\hline & \multicolumn{3}{|c|}{ Polinomial Regression } \\
\hline 0 & 4,83 & 2430,00 & \\
\hline 30 & 4,86 & 2807,00 & \\
\hline 60 & 4,63 & 3027,00 & \\
\hline 90 & 4,75 & 3108,00 & \\
\hline $\mathrm{p}>\mathrm{F}$ (linear) & 0,40 & 0,004 & \\
\hline $\mathrm{p}>\mathrm{F}$ (quadratic) & 0,71 & 0,35 & \\
\hline$r^{2}($ linear $\%)$ & 37,15 & 92,09 & \\
\hline \multirow[t]{2}{*}{$r^{2}$ (quadratic \%) } & 44,31 & 99,99 & \\
\hline & \multicolumn{3}{|c|}{ Polinomial Equation } \\
\hline
\end{tabular}

$\mathrm{Y}=2504,91+7,518481 \mathrm{x}$

$* * *$ Significant at levels of $1 \%$ and $5 \%$, respectively, by the $\mathrm{F}$ Test of the analysis of variance.

\section{Conclusions}

The results obtained during the assessments years of this study enabled concluding that after planting the cover crops, the yield and development of cotton plant heights increased with the use of pre-sowing $\mathrm{N}$ by $90 \mathrm{~kg} \mathrm{ha}^{-1}$ and also that the forage turnip is a cover crop that provides increased cotton.

\section{References}

EMPRESA BRASILEIRA DE PESQUISA AGROPECUÁRIA - EMBRAPA. Sistema brasileiro de classificação de solos. 2. ed. Rio de Janeiro: Brasília,
2006. $306 \mathrm{p}$.

FURLANI JÚNIOR, E.; SILVA, N. M.; CARVALHO, L. H.; BORTOLETTO, N.; SABINO, J. C.; BOLONHEZI, D. Modos de aplicação do regulador vegetal no algodoeiro, cultivar IAC-22, em diferentes densidades populacionais e níveis de nitrogênio em cobertura. Bragantia, Campinas, v. 62, n. 2, p. 227-233, 2003.

GOMES, P. F. Curso de estatística experimental. Piracicaba: USP, 2000. 477 p.

GUIDELI, C.; FAVORETO, V.; MALHEIRIOS, E. B. Produção e qualidade do milheto semeado em duas épocas e adubado com nitrogênio. Pesquisa Agropecuária Brasileira, Brasília, v. 35, n. 10, p. 2093-2098, 2000.

HOLDERBAUM, J. F.; DECKER, A. M.; MEISINGER, 
J. J.; MULFORED, F. R.; VOUGH, L. R. Fall seeded legume cover crops for not-tillage corn in the humid East. Agronomy Journal, New York, v. 82, n. 1, p. $117-$ 124, 1990.

LAMAS, F. M.; STAUT, L. A. Nitrogênio e cloreto de mepiquat na cultura do algodoeiro. Revista Ceres, Viçosa, v. 51, n. 298, p. 755-764, 2005.

LIMA, M. M. de; AZEVEDO, C. A. V.; BELTRÃO, N. E. M.; DANTAS NETO, J.; GONÇALVES, C. B.; SANTOS, C. G. F. Nitrogênio e promotor de crescimento: efeitos no crescimento e desenvolvimento do algodão colorido verde. Revista Brasileira de Engenharia Agrícola e Ambiental, Campina Grande, v. 10, n. 3, p. 624-628, 2006.

MEINSINGER, J. J.; HARGROVE, W. L.; MIKKELSON, R. L.; WILLIAMS, J. R.; BENSON, J. W. Effects of cover crops on gound water quality. In: HARGROVE, W. L. (Ed.). Cover crops for clean water. Ankeny: Soil and Water Conservation Society, 1991. p. 115-117.

RAIJ, B. V. QUAGGIO, J. A. Métodos de análises de solos para fins de fertilidade. Campinas: Instituto Agronômico, 1983, 31 p. (Boletim técnico, 81).

ROTH, C.; VIEIRA, M. J. Infiltração de água no solo. Plantio Direto, Viçosa, v. 1, n. 1, p. 4, 1983.

SILVA, M. N. B.; PITOMBEIRA, J. B.; BELTRÃO, E. M.; SILVA, F. P. População de plantas e adubação nitrogenada em algodoeiro herbáceo irrigado. I. Rendimento e característica da fibra. Revista Brasileira de Oleaginosas e Fibrosas, Campina Grande, v. 5, n. 2, p. 355-361, 2001.

SILVA, N. M.; KONDO, J. I.; SABINO, N. P. Importância da adubação na qualidade do algodão e outras plantas fibrosas. In: SÁ, M. E.; BUZZETI, S. (Ed.). Importância da adubação na qualidade dos produtos agrícolas. São Paulo: Ícone, 1994. p. 189-216.

SILVA, N. M. Nutrição mineral e adubação do algodoeiro no Brasil. In: CIA, E.; FREIRE, E. C.; SANTOS, W. J. (Ed.). Cultura do Algodoeiro. Piracicaba: POTAFÓS, 1999. p. 57-92.

SILVA, N. M.; CARVALHO, L. H.; CANTARELLA, H.; BATAGLIA, O. C.; KONDO, J. I.; SABINO, J. S.; BORTOLETO, N. Uso de sulfato de amônia e de Uréia na adubação do algodoeiro. Bragantia, Campinas, v. 52, n. 1, p. 69-81, 1993.

SILVA, N. M.; RAIJ, B. van. Fibrosas. In: RAIJ, B. van; CANTARELLA, H.; QUAGGIO, J. A.; FURLANI, A. M. C. (Ed.). Recomendações de adubação e calagem para o Estado de São Paulo. 2. ed. Campinas: Instituto Agronômico/Fundação IAC, 1997. cap. 16, p. 107-111.
(Boletim técnico, 100).

TEIXEIRA, I. R.; KIKUTI, H.; BORÉM, A. Crescimento e produtividade de algodoeiro submetido a cloreto de mepiquat e doses de nitrogênio. Bragantia, Campinas, v. 67, n. 4, p. 891-897, 2008.

WANG, J.; HESKETH, J. D.; WOOLLEY, J. T. Preexisting channels and soybean rooting patterns. Soil Science, Madison, v. 141, n. 5, p. 432-437, 1986.

WIATRAK, P. J.; WRIGHT, D. L.; MAROIS, J. J.; KOZIARA, W.; PUDELKO, J. A. Tillage and nitrogen application impact on cotton following wheat. Agronomy Journal, Madison, v. 97, n. 1, p. 288-293, 2005. 
